\title{
Aktivitas Antibakteri Ekstrak Etanol Dari Lima Tanaman Terhadap Bakteri Staphylococcus Epidermidis Dengan Metode Mikrodilusi M7 - A6CLSI
}

\author{
${ }^{1,2}$ Shendi Suryana, ${ }^{2}$ Yen Yen Ade Nuraeni , ${ }^{1}$ Tina Rostinawati \\ ${ }^{1}$ Fakultas Farmasi, Universitas Padjadjaran, Bandung, Jawa Barat, Indonesia \\ ${ }^{2}$ Fakultas MIPA, Jurusan Farmasi, Universitas Garut, Garut, Jawa Barat, Indonesia
}

\begin{abstract}
Abstrak
Telah dilakukan penelitian uji aktivitas antibakteri dari ekstrak etanol daun Leucaena leucocephala, Camellia sinensis, Psidium guajava L, Anredera cordifolia (Ten.) Steenis dan Solanum nigrum L. terhadap Staphylococcus epidermidis menggunakan metode mikrodilusi. Sebagai pembanding digunakan antibiotik tetrasiklin $\mathrm{HCl}$, kloramfenikol dan amoksisilin. Ekstrak etanol Leucaena leucocephala, Camellia sinensis dan Psidium guajava L memiliki aktivitas sebagai antibakteri, sedangkan ekstrak etanol uji lainnya memiliki aktivitas antibakteri yang tidak signifikan. Nilai Konsentrasi Hambat Minimum (KHM) ekstrak etanol Leucaena leucocephala terhadap Staphylococcus epidermidis adalah 62,5 $\mu \mathrm{g} / \mathrm{ml}$. Nilai Konsentrasi Bakterisidal Minimum (KBM) ekstrak etanol Camellia sinensis dan Psidium guajava Ladalah $125 \mu \mathrm{g} / \mathrm{ml}$.
\end{abstract}

Kata kunci: Mikrodilusi, tetrasiklin $\mathrm{HCl}$, kloramfenikol, amoksisilin, KHM dan KBM

\section{Antibacterial Activity Of Five Plant Ethanol Extract Against Staphylococcus Epidermidis Bacteria With Microdilution M7 - A6CLSI Method}

\begin{abstract}
The antibacterial activity of Leucaena leucocephala, Camellia sinensis, Psidium guajava L, Anredera cordifolia (Ten.) Steenis and Solanum nigrum L. leafs ethanol extract against Staphylococcus epidermidis using microdillution method has been studied. Using microdillution method with tetracycline, chloramfenicol and amoxicillin as antibiotic reference. Leucaena leucocephala, Camellia sinensis and Psidium guajava L. leafs ethanol extract had activity to inhibit bacteria. And the other leafs ethanol extract had unsignificant activity againts bacteria. The Minimum Inhibitory Concentration (MIC) of Leucaena leucocephala leafs ethanol extract againts Staphylococcus epidermidis were $62,5 \mu \mathrm{g} / \mathrm{ml}$. The Minimum Bactericidal Concentration (MBC) of Camellia sinensis and Psidium guajava L were $125 \mu \mathrm{g} /$ $\mathrm{ml}$.
\end{abstract}

Keywords: Microdillution, Staphylococcus epidermidis, tetracycline, chloramfenicol, amoxcillin, $\mathrm{MIC}$ and $\mathrm{MBC}$ 


\section{Pendahuluan}

Jerawat merupakan kelainan kulit yang dikenal dengan acne vulgaris ${ }^{1}$ Biasanya jerawat menyerang seseorang yang memasuki masa puber, atau remaja dengan gambaran klinis berupa komedo, papul, pustul, nodus dan kista pada muka, bahu, leher, dada, punggung bagian atas dan lengan bagian atas ${ }^{2}$. Pada kulit terutama wajah, jerawat berbentuk benjolan kecil, berkepala kuning, berisi nanah, gatal dan sedikit nyeri ${ }^{3}$. Pengobatan jerawat dilakukan dengan memperbaiki abnormalitas folikel, menurunkan produksi sebum yang berlebih, menurunkan jumlah koloni $P$. acnes, $S$. aureus, $S$. epidermidis dan $P$. ovale yang merupakan bakteri penyebab jerawat dan menurunkan inflamasi pada kulit ${ }^{4}$. Bakteri tersebut ikut serta dalam patogenesis jerawat dengan menghasilkan lipase, yang memecahkan asam lemak bebas dari lipid kulit ${ }^{5}$. Asam lemak ini dapat menimbulkan radang jaringan dan ikut menyebabkan jerawat ${ }^{6}$. Populasi bakteri penyebab jerawat tersebut dapat diturunkan dengan memberikan suatu zat antibakteri seperti tetrasiklin, kloramfenikol dan amoksisilin ${ }^{7}$.

Beberapa contoh antibakteri yang dapat diperoleh dari alam yang memiliki aktivitas untuk menghambat pertumbuhan bakteri penyebab jerawat adalah Daun petai cina (Leucaena leucocephala), daun teh (Camellia sinensis), daun Jambu Biji (Psidium guajava L), daun binahong (Anredera cordifolia (Ten.) Steenis) dan daun leunca (Solanum nigrum L). Daun petai cina telah dibuktikan bermanfaat dalam pengobatan dan memiliki kandungan kimia tanin, saponin dan alkaloid yang mempunyai daya antibakteri yang kuat ${ }^{8}$. Ekstrak daun teh mempunyai kandungan quertin, epigallocathecin gallate dan poliphenol yang diduga mempunyai efek antibakteri sehingga mampu menghambat pertumbuhan bakteri'. Dalam daun jambu biji terkandung senyawa polifenol, karoten, flavonoid, saponin dan tanin. Daun jambu biji memiliki khasiat sebagai anti inflamasi, antimutagenik, antimikroba dan analgesik ${ }^{10}$. Pada ekstrak daun binahong ditemukan senyawa polifenol, alkaloid dan flavonoid yang pada konsentrasi $25 \%$ dan 50\% dapat menghambat pertumbuhan bakteri Shigella flexneri ${ }^{11}$. Kandungan metabolit sekunder pada daun leunca seperti Solasodine mempunyai efek menghilangkan sakit (analgetik), penurunan panas, antiradang, dan antishok. Solamargine dan solasonine mempunyai efek antibakteri, sedangkan solanine sebagai antimitosis ${ }^{12}$.

Pada penggunaannya obat jerawat yang ada di pasaran memiliki efek samping yang lebih besar daripada obat jerawat yang berasal dari alam ${ }^{13}$, misalnya efek samping yang diakibatkan dari antibiotik yang digunakan pada produk anti jerawat yang ada di pasaran yaitu reaksi alergi yang diakibatkan oleh antibiotik dengan melibatkan sistem imun tubuh hospes. Selain itu efek samping yang ditimbulkan yaitu reaksi hipersensitifitas ${ }^{6}$, adanya ketergantungan obat yang terjadi karena interaksi suatu obat dengan organisme hidup $^{7}$, ada suatu senyawa yaitu Isotretinoin yang digunakan untuk mengobati jerawat yang berat ${ }^{13}$, psoriasis dan kelainan kulit lainnya bisa menyebabkan cacat bawaan ${ }^{14}$. Yang paling sering terjadi adalah kelainan jantung, telinga yang kecil dan hidrosefalus (kepala yang besar) ${ }^{15}$. Resiko terjadinya cacat bawaan adalah sebesar $25 \%{ }^{16}$. Obat jerawat yang beredar dipasaran memiliki efek samping yang lebih besar ${ }^{17}$.

Pengujian konsentrasi hambat minimum dan konsentrasi bakterisidal minimum dari ekstrak etanol tumbuh-tumbuhan yang sudah dijelaskan di atas dilakukan untuk mengetahui jenis tumbuhan mana yang memiliki aktivitas antibakteri lebih besar terhadap bakteri penyebab jerawat. Bakteri yang digunakan pada penelitian ini adalah bakteri Staphylococcus epidermidis.

\section{Metode}

Pengujian aktivitas antibakteri dilakukan dengan menggunakan metode 
difusi agar untuk mengetahui aktivitas antibakteri ekstrak etanol daun petai cina ( $L$. leucocephala), teh (C. sinensis), jambu biji ( $P$. guajava L), binahong ( $A$. cordifolia (Ten.) Steenis) dan leunca $(S$. nigrum L) terhadap bakteri Staphylococcus epidermidis.

Penentuan Konsentrasi Hambat Minimum (KHM) dilakukan dengan menggunakan metode mikrodilusi dengan serangkaian seri pengenceran ekstrak etanol tanaman uji pada media yang kemudian diinokulasi dengan bakteri. Dilakukan juga pengujian kesetaraan aktivitas zat uji dengan antibiotik pembanding,yaitu Tetrasiklin hidroklorida, Kloramfenikol dan Amoksisilin.

\section{Alat}

Alat yang digunakan antara lain autoklave, corong, pipet tetes, mikro pipet, pembakar spirtus, cawan petri, mikrotiter plate, tabung reaksi, pinset, gelas ukur, gelas kimia, erlenmeyer, kawat ose, inkubator, batang pengaduk, termometer, spatel, kompor listrik, perforator, neraca analitik, alumunium foil, kapas non lemak, botol infus, jangka sorong, spektrometer, vial dan alat-alat gelas lain yang biasa digunakan dalam Laboratorium Mikrobiologi.

\section{Bahan}

Tanaman Uji yang digunakan adalah daun petai cina (L. leucocephala), teh (C. sinensis), jambu biji (P. guajava $\mathrm{L}$ ), binahong (A. cordifolia (Ten.) Steenis) dan leunca (S. nigrum L).

Bahan Kimia yang digunakan adalah $\mathrm{NaCl}$ Fisiologis, air suling steril dan media yang digunakan yaitu Nutrient Agar (NA), Mueller Hinton Broth (MHB) serta Antibiotik pembanding yaitu Tetrasiklin hidroklorida, Kloramfenikol dan Amoksisilin.

Bakteri Uji yang digunakan antara lain Staphylococcus epidermidis.

Prosedur

1. Sterilisasi Alat
Semua alat yang akan digunakan terlebih dahulu disterilkan melalui proses sterilisasi yang terdiri dari sterilisasi kering dengan api langsung dan oven pemanas dan sterilisasi basah dengan menggunakan autoklave pada suhu $121^{\circ} \mathrm{C}$ selama 15 menit ${ }^{18}$.

\section{Pembuatan Media Agar}

Sebanyak 23 gram serbuk agar dilarutkan dalam air suling steril sebanyak 1 liter, kemudian dipanaskan hingga larut dalam labu erlenmeyer. Mulut labu erlenmeyer disumbat menggunakan kapas berlemak dan ditutup oleh aluminium foil lalu disterilisasikan dengan autoklave pada suhu $1210 \mathrm{C}$ selama 15 menit $^{19}$.

\section{Pembuatan Larutan Stok}

Dilarutkan $100 \mathrm{mg}$ tiap sampel dalam $1 \mathrm{ml} \mathrm{DMSO} \mathrm{100 \%} \mathrm{(100} \mathrm{mg/ml).} \mathrm{Untuk}$ mendapatkan konsentrasi larutan sampel 1 mg atau $1000 \mu \mathrm{g}$ dilakukan pengenceran dari $100 \mathrm{mg} / \mathrm{ml}, 10$ kalinya menjadi 10 $\mathrm{mg} / \mathrm{ml}$ setelah itu dilakukan pengenceran kembali menjadi 10 kalinya menjadi $1 \mathrm{mg} /$ $\mathrm{ml}$ atau $1000 \mu \mathrm{g} / \mathrm{ml}^{20}$.

\section{Pembuatan Stok Bakteri}

Dalam membuat stok bakteri ini digunakan inokulum standar yaitu stok bakteri $10^{8} \mathrm{CFU} / \mathrm{ml}$ sama dengan 0,5 McFarland standard ${ }^{21}$.

\section{Uji Kepekaan}

Uji Kepekaan Antimikroba menggunakan Metode Agar: dicampurkan nutrien agar dengan bakteri, dimasukan kedalam cawan petri, didiamkan sampai media memadat. Pada media tersebut buat sumur dengan perforator, dimasukan $50 \mu \mathrm{l}$ larutan stok pada sumur tersebut, diinkubasi selama $18-24$ jam pada suhu $37^{\circ} \mathrm{C}$, dilihat hasil dan ukur diameter hambatnya ${ }^{17}$. Hasil uji dapat dilihat pada Tabel .3

Uji Kepekaan dengan Metode Microdillution broth, metode ini menggunakan standar yang terdapat di CLSI M7-A6 guidelines. Dicampurkan 
Tabel 1 Hasil Penapisan Senyawa Kimia Senyawa Uji

\begin{tabular}{lcccccc}
\hline \multirow{2}{*}{ No } & \multirow{2}{*}{ Parameter } & \multicolumn{5}{c}{ Hasil Pengamatan } \\
\cline { 2 - 7 } & Petai Cina & Teh & Binahong & Jambu Biji & Leunca \\
\hline 1 & Alkaloid & + & + & + & + & + \\
2 & Flavonoid & + & + & + & + & - \\
3 & Saponin & + & + & + & + & - \\
4 & Tanin & + & + & - & + & - \\
5 & Kuinon & - & + & - & + & + \\
6 & Steroid/Triterpenoid & - & + & + & + & + \\
\hline
\end{tabular}

Keterangan :

$(+)$ : Terdeteksi, (-) : Tidak terdeteksi

larutan sampel dalam medium Mueller hinton broth (MHB) yang mengandung 5 x $10^{5} \mathrm{CFU} / \mathrm{ml}$ koloni, disiapkan mikrotiter plate yang terdiri dari 96 sumur atau 12 kolom dan 8 baris, kolom 1 diisi dengan media saja (MHB) sebagai kontrol negatif sebanyak $100 \mu 1$., kolom 2-12 diisi dengan MHB dan bakteri sebagai kontrol positif sebanyak $100 \mu \mathrm{l}$ yang diambil dari stok bakteri dan MHB yang telah dicampurkan sebelumnya. Homogenkan. Jadi tiap sumur terdapat $5 \times 10^{4} \mathrm{CFU} / \mathrm{ml}$ koloni. Pada kolom 12, baris 1 sampai 5 diisi dengan sampel yang berbeda dan baris 6 sampai 8 diisi dengan antibiotik yang berbeda juga masing-masing sebanyak $100 \mu \mathrm{l}$ dan dihomogenkan, dari kolom 12 tersebut, diambil sebanyak $100 \mu \mathrm{l}$ dan masukan kedalam kolom 11. dari kolom 11 diambil sebanyak $100 \mu \mathrm{l}$ dan masukan kedalam kolom 10 begitu seterusnya sampai kolom 318. Dari kolom 3, diambil sebanyak $100 \mu 1$ dan dibuang. diinkubasikan mikrotiter plate pada suhu $37^{\circ} \mathrm{C}$ selama $18-24$ jam, dilihat apakah hasilnya bening atau ada endapan, jika pada sumur 4 bening sedangkan pada well 1,2 dan 3 ada endapan, maka pada sumur 4 menunjukan nilai KHM. Karena sumur $4-12$ berwarna bening maka dari sumur 4 -12 diambil (di droping) sebanyak $20 \mu$ l. Masukan ke cawan petri yang berisi Nutrien Agar (NA), diinkubasi cawan petri tersebut pada suhu $37^{\circ} \mathrm{C}$ selama $18-24$ jam. Jika tidak ada pertumbuhan maka disebut KBM.

Misal : nilai KHM pada sumur 4, maka yang di drop yaitu sumur 4-12, setelah di drop ternyata pada sumur 5 ada pertumbuhan sedangkan sumur 6-12 tidak ada maka nilai KBM yaitu pada sumur 6 .

Tabel 2 Hasil Pemeriksaan Karakteristik Simplisia Uji

\begin{tabular}{ccccccc}
\hline & & \multicolumn{4}{c}{ Kadar Tanaman Uji (100\%) } \\
\cline { 3 - 6 } No & Pemeriksaan & $\begin{array}{c}\text { Jambu } \\
\text { Biji }\end{array}$ & Petai Cina & Teh & Binahong & Leunca \\
\hline 1 & Kadar abu total & 8,5 & 8,2 & 4,64 & 23,8 & 12,0 \\
2 & Kadar abu larut air & 2,59 & 2,1 & 1,4 & 4,7 & 5,4 \\
3 & Kadar abu tidak larut & 0,07 & 0,73 & 0,02 & 2,1 & 4,1 \\
& asam & & & & 5,2 & 6,5 \\
4 & Kadar sari larut air & 10,3 & 4,25 & 11,6 & 19,8 & 11,7 \\
5 & Kadar sari larut etanol & 12,4 & 11,28 & 15,5 & 8 & 8,5 \\
6 & Kadar air & 8,0 & 8,4 & 6,5 & 13 & 9,6 \\
\hline
\end{tabular}




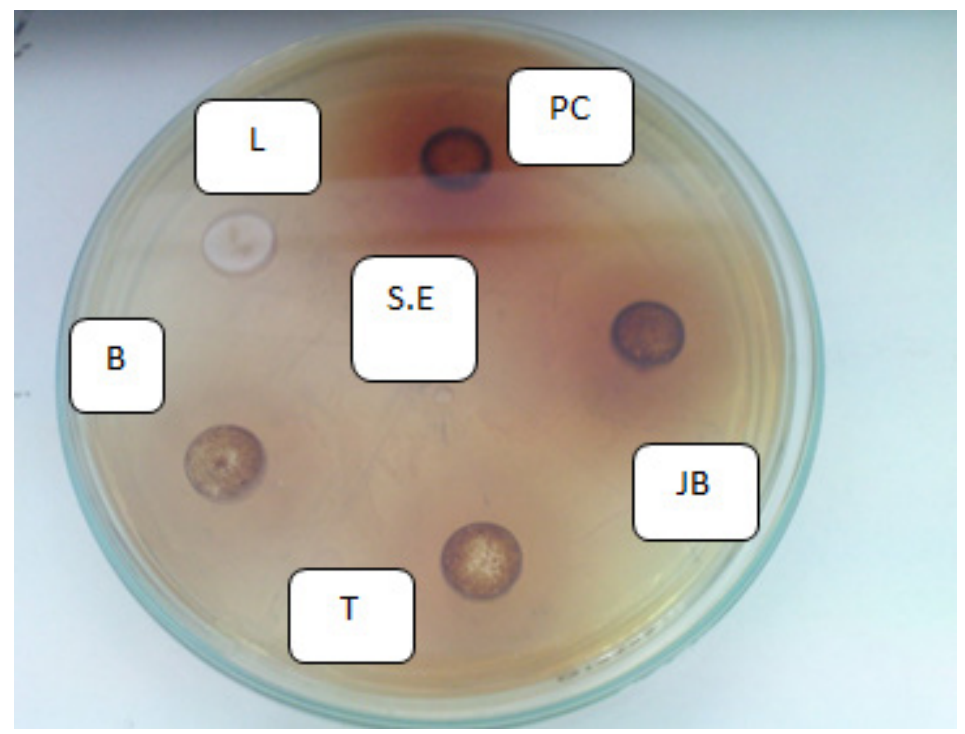

Gambar IV.6 Hasil uji aktivitas antibakteri ekstrak etanol tanaman leunca (Solanum nigrum L), teh (Camellia sinensis), binahong (Anredera cordifolia (Ten.) Steenis), petai cina (Leucaena leucocephala) dan jambu biji (Psidium guajava L) terhadap S. epidermidis

Keterangan:

$\mathrm{T}$ : teh, B: binahong, PC: petai cina, JB: jambu biji, L: leunca ; masing-masing tanaman dengan konsentrasi $100 \mathrm{mg} / \mathrm{ml}$

\section{Hasil dan Pembahasan}

Hasil penapisan fitokimia menunjukan bahwa kelima tanaman positif mengandung alkaloid. Flavonoid ditemukan pada petai cina, teh, binahong dan jambu biji. Pada leunca tidak ada flavonoid. Saponin ditemukan pada petai cina, teh, binahong dan jambu biji. Pada leunca tidak ada saponin. Tanin ditemukan pada petai cina, teh dan jambu biji. Binahong dan leunca tidak mengandung tanin. Kuinon dan steroid/triterpenoid ditemukan pada teh, binahong, jambu biji dan leuca. Pada petai cina tidak ditemukan kuinon dan steroid/ triterpenoid.

Pengujian aktivitas ekstrak etanol tanaman terhadap Staphylococcus epidermidis menunjukan bahwa kelima ekstrak etanol uji dengan konsentrasi masing-masing sebesar $100 \mathrm{mg} / \mathrm{ml}$ dapat menghambat pertumbuhan Staphylococcus epidermidis. Zona hambat terbesar diberikan oleh ekstrak petai cina dengan zona hambat sebesar 17,33 mm dan zona hambat terkecil diberikan oleh ekstrak leunca dengan zona hambat sebesar 10,34 mm. Hasil Pengujian dapat dilihat pada Tabel.3

Dilihat dari kandungan kimia, petai cina kuinon dan steroid/triterpenoid tapi aktivitas antibakterinya paling besar. Sedangkan pada leunca tidak ditemukan flavonoid, saponin dan tanin, dimana aktivitas antibakterinya paling lemah. Hanya binahong yang tidak memiliki alkaloid tapi memilki aktivitas antibakteri, artinya aktivitas tersebut tidak dipengaruhi oleh kandungan alkaloid, tetapi lebih kepada pengaruh flavonoid, tanin atau

Tabel 3. Hasil Uji Aktivitas Ekstrak Etanol Tanaman terhadap Staphylococcus epidermidis

\begin{tabular}{clc}
\hline No & Ekstrak & Zona Hambat $(\mathbf{m m})$ \\
\hline 1 & Leunca & 10,34 \\
2 & Teh & 15,84 \\
3 & Binahong & 15,65 \\
4 & Petai cina & 17,33 \\
5 & Jambu biji & 16,25 \\
\hline
\end{tabular}




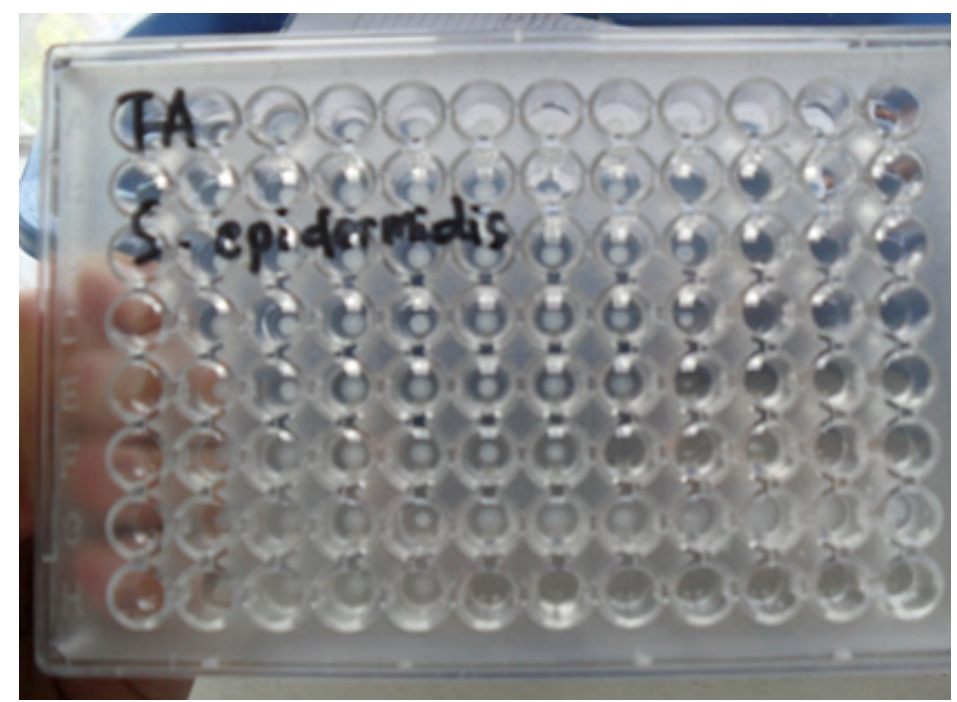

Gambar IV.7 Hasil uji konsentrasi hambat minimum ekstrak etanol tanaman leunca (Solanum nigrum L), teh (Camellia sinensis), binahong (Anredera cordifolia (Ten.) Steenis ), petai cina (Leucaena leucocephala) jambu biji (Psidium guajava L) serta tetrasiklin, kloramfenikol dan amoksisilin terhadap S. epidermidis

Keterangan:

A1-H1 (Kontrol Positif) : MHB; A2-H2 (Kontrol Negatif) : MHB + Bakteri; A,B,C,D,E,F,G,H (3-12) : MHB + Bakteri + Sampel uji; A12 : Ekstrak Leunca, B12 : Ekstrak Teh, C12 : Ekstrak Binahong, D12 : Ekstrak Petai cina, E12 : Ekstrak Jambu Biji, F12 : Tetrasiklin, G12 : Kloramfenikol, H12 : Amoksisilin

saponin.

Pada penentuan Konsentrasi Hambat Minimum (KHM) dapat diketahui bahwa kelima ekstrak etanol uji termasuk pembanding memiliki daya hambat terhadap pertumbuhan Staphylococcus epidermidis dengan nilai KHM yang berbeda. Ekstrak etanol daun leunca, teh, binahong dan jambu biji memiliki nilai KHM yang sama yaitu sebesar $125 \mu \mathrm{g} / \mathrm{ml}$. Akan tetapi, ekstrak etanol daun petai cina dengan nilai KHM sebesar $62,5 \mu \mathrm{g} / \mathrm{ml}$ memiliki daya hambat

Tabel 4. Hasil Penentuan KHM Ekstrak Etanol Tanaman terhadap Staphylococcus epidermidis

\begin{tabular}{llcc}
\hline No & Sampel & Sumur & $\begin{array}{c}\text { Konsentrasi } \\
(\boldsymbol{\mu g} / \mathbf{m l})\end{array}$ \\
\hline 1 & Leunca & A10 & 125 \\
2 & Teh & B10 & 125 \\
3 & Binahong & C10 & 125 \\
4 & Petai cina & D9 & 62,5 \\
5 & Jambu biji & E10 & 125 \\
6 & Tetrasiklin & F7 & 3,9 \\
7 & Kloramfenikol & G7 & 3,9 \\
8 & Amoksisilin & H8 & 7,8 \\
\hline
\end{tabular}

terhadap pertumbuhan Staphylococcus epidermidis lebih baik dibandingkan dengan ekstrak etanol daun leunca, teh, binahong dan jambu biji. Hasil Pengujian dapat dilihat pada Tabel .4.

Penentuan Konsentrasi Bakterisidal Minimum (KBM) menunjukan bahwa kelima ekstrak etanol uji dan Pembanding memiliki daya bakterisidal terhadap Staphylococcus epidermidis dengan nilai KBM yang berbeda. Ekstrak teh dan jambu biji dengan nilai KBM yang sama

Tabel 5. Hasil Penentuan KBM Ekstrak Etanol Tanaman terhadap Staphylococcus epidermidis

\begin{tabular}{llcc}
\hline No & Sampel & Sumur & $\begin{array}{c}\text { Konsentrasi } \\
(\boldsymbol{\mu g} / \mathbf{m l})\end{array}$ \\
\hline 1 & Leunca & A11 & 250 \\
2 & Teh & B10 & 125 \\
3 & Binahong & C12 & 500 \\
4 & Petai cina & D11 & 250 \\
5 & Jambu biji & E10 & 125 \\
6 & Tetrasiklin & F8 & 7,8 \\
7 & Kloramfenikol & G9 & 15,6 \\
8 & Amoksisilin & H10 & 31,25 \\
\hline
\end{tabular}


Tabel 6. Kesetaraan Nilai KHM Petai Cina Terhadap Antibiotik

\begin{tabular}{llc}
\hline & & \multicolumn{1}{c}{ Tanaman } \\
\cline { 3 - 3 } No & Antibiotik & $\begin{array}{c}\text { Petai Cina (1 bagian } \\
\text { konsenrasi ekstrak) }\end{array}$ \\
\hline 1 & Tetrasiklin & 0,062 \\
2 & Kloramfenikol & 0,062 \\
3 & Amoksisilin & 0,125 \\
\hline
\end{tabular}

yaitu sebesar $125 \mu \mathrm{g} / \mathrm{ml}$ memiliki daya bakterisidal yang lebih baik terhadap Staphylococcus epidermidis dibandingkan dengan ekstrak uji yang lain.

Bila dilihat dari nilai KHM, petai cina menunjukan aktivitas yang terbaik dibandingkan 4 tanaman yang lain, namun bila dilihat dari nilai KBM, teh dan jambu
Tabel 7. Kesetaraan Nilai KBM Tanaman Terhadap Antibiotik

\begin{tabular}{cccc}
\hline \multirow{2}{*}{ No } & \multirow{2}{*}{ Antibiotik } & \multicolumn{2}{c}{ Tanaman } \\
\cline { 3 - 4 } & & $\begin{array}{c}\text { 1 bagian konsenrasi } \\
\text { ekstrak }\end{array}$ \\
\cline { 3 - 4 } & & Teh & Jambu biji \\
\hline 1 & Tetrasiklin & 0,06 & 0,06 \\
2 & Kloramfenikol & 0,125 & 0,125 \\
3 & Amoksisilin & 0,25 & 0,25 \\
\hline
\end{tabular}

biji menunjukkan aktivitas terbaik. Hal ini menunjukan mekanisme dari ektrak petai cina bekerja secara bakeriostatik sedangkan teh dan jambu biji bekerja secara bakterisid. Bila dihubungkan dengan kandungan kimia, pada teh dan jambu biji ini memiliki kuinon dan steroid/triterpenoid, kedua metabolit sekunder ini tidak ditemukan pada petai cina.

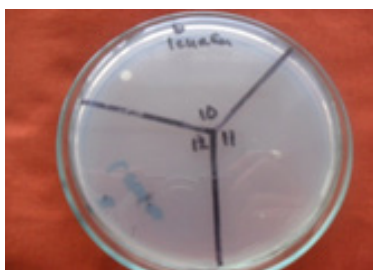

(a)

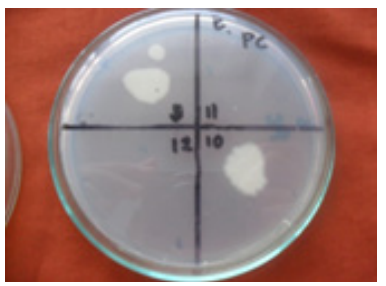

(d)

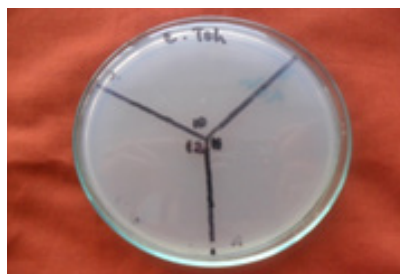

(b)

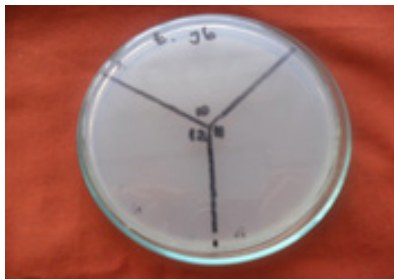

(e)

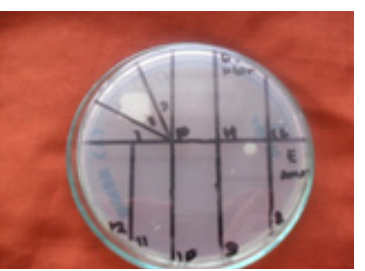

(f)

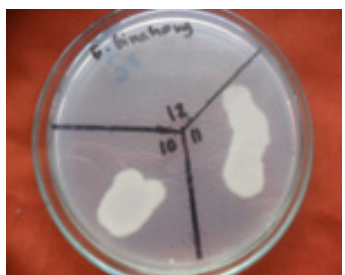

(c)

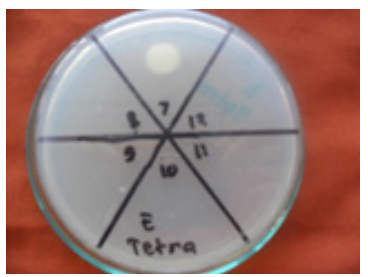

(f)

Gambar IV.7 Hasil uji konsentrasi bakterisidal minimum ekstrak etanol tanaman leunca (Solanum nigrum L), teh (Camellia sinensis), binahong (Anredera cordifolia (Ten.) Steenis ), petai cina (Leucaena leucocephala) jambu biji (Psidium guajava L) serta tetrasiklin, kloramfenikol dan amoksisilin terhadap S. epidermidis 
Dengan demikian untuk kerja bakteriostatk senyawa yang berpengaruh adalah flavonoid, tanin dan saponin. Sedangkan untuk kerja bakterisid dipengaruhi oleh kuinon dan steroid/triterpenoid.

Pada penetuan KHM, nilai kesetaraan 1 bagian konsentrasi ekstrak petai cina terhadap tetrasiklin dan kloramfenikol adalah 0,062 sedangkan terhadap amoksisilin adalah sebesar 0,125. Pada penentuan KBM, nilai kesetaraan 1 bagian ekstrak teh dan jambu biji terhadap tetrasiklin adalah 0,062, kloramfenikol 0,125 dan terhadap amoksisilin adalah 0,25.

Bila dilihat dari harga kesetaraan, aktivitas ekstrak kelima tanaman ini masih belum sekuat antibiotik pembanding, hal ini mengingat pada ekstrak efek yang dihasilkan merupakan hasil kerja gabungan dari berbagai senyawa metabolit sekunder, belum berupa zat murni. Untuk pengembangan lebih lanjut perlu adanya upaya mengisolasi senyawa murni untuk uji aktivitas antibakteri.

\section{Simpulan}

Dari penelitian yang telah dilakukan dapat disimpulkan bahwa pada penentuan aktivitas antibakteri dari kelima tanaman uji, tanaman yang memiliki aktivitas antibakteri paling besar adalah petai cina dengan zona hambat sebesar 17,33 mm. Pada penentuan KHM, petai cina juga memiliki aktivitas antibakteri paling besar dengan nilai KHM $62,5 \mu \mathrm{g} / \mathrm{ml}$. Penentuan konsentrasi bakterisidal minimum (KBM) menunjukan bahwa tanaman yang memiliki aktivitas antibakteri yang paling besar adalah teh dan jambu biji dengan nilai KBM yaitu $125 \mu \mathrm{g} / \mathrm{ml}$.

Pada penetuan KHM, nilai kesetaraan 1 bagian konsentrasi ekstrak petai cina terhadap tetrasiklin dan kloramfenikol adalah 0,062 sedangkan terhadap amoksisilin adalah sebesar 0,125. Pada penentuan KBM, nilai kesetaraan 1 bagian ekstrak teh dan jambu biji terhadap tetrasiklin adalah 0,062, kloramfenikol
0,125 dan terhadap amoksisilin adalah 0,25.

\section{Daftar Pustaka}

1. Muddathir AM, Mitsunaga T. Evaluation of anti-acne activity of selected Sudanese medicinal plants. $J$ Wood Sci. 2013;59(1):73-79. doi:10.1007/s10086012-1303-5.

2. Dreno B. Topical antibacterial therapy for acne vulgaris. Drugs. $\quad$ 2004;64(21):2389-2397. doi:10.2165/00003495-20046421000002.

3. Daud FS, Pande G, Joshi M, Pathak R, Wankhede S. A study of antibacterial effect of some selected essential oils and medicinal herbs against acne causing bacteria. Int J Pharm Sci Invent. 2013;2(1):27-34.

4. Sohn HY, Kim YS, Kum EJ, Kwon YS, Son KH. Screening of anti-acne activity of natural products against Propionibacterium acnes. Korean $J$ Microbiol Biotechnol. 2006;34(3):265272.

5. Tahir CM. Pathogenesis of acne vulgaris: Simplified. J Pakistan Assoc Dermatologists. $\quad$ 2010;20(2):93-97. doi:10.1016/j.pmr.2005.12.012.

6. Zouboulis CC, Bettoli V. Management of severe acne. $\mathrm{Br} J$ Dermatol. 2015;172(S1):27-36. doi:10.1111/ bjd.13639.

7. James K a, Burkhart CN, Morrell DS. Emerging drugs for acne. Expert Opin Emerg Drugs. 2009;14(4):649-659. doi:10.1517/14728210903251690.

8. Andriana, Ahmad Lani. Uji daya antibakteri ekstrak etanol daun petai cina (leucaena leucocephala 1.) Terhadap multidrug resistant acinetobacter baumannii secara in vitro. Medicinal plants infection - medicine . Banda Aceh : Universitas Syiah Kuala, 2014.

9. Yuwono, aurent Febrilia. Daya Antibakteri Ekstrak Daun Teh (Camellia sinensis) Terhadap Pertumbuhan Streptococcus sp. pada Plak Gigi Invitro. 
Fakultas Kedokteran, Universitas Sebelas Maret, Surakarta. 2009.

10. Indriani, S. Aktifitas Antioksidan Ekstrak Daun Jambu Biji (Psidium guajava L.) .J.II.Pert.Indon,11(1). 2006.

11. Ainurrochma, A., Evie, R., Lisa, L. 2013. Efektivitas Ekstrak Daun Binahong (Anredera cordifolia) terhadap Penghambatan Pertumbuhan Bakteri Shigella flexneri dengan Metode Sumuran. LenteraBio. 2013; 3(2) : 233237.

12. Parameswari.K, Sudheer Aluru and Kishori. B. In Vitro Antibacterial Activity In The Extracts Of Solanum Nigrum. Indian Streams Research Journal. 2012; 2(7): 1-5.

13. Wolverton SE, Harper JC. Important controversies associated with isotretinoin therapy for acne. $A m J$ Clin Dermatol. 2013;14(2):71-76. doi:10.1007/s40257-013-0014-z.

14. El-Shahawy MA, Gadallah MF, Massry, SG, M.A.E-S, M.F.G, S.G.M. Acne: A potential side effect of cyclosporine A therapy. Nephron. 1996; 72(4): 679682.

15. Tripathi S V, Gustafson CJ, Huang KE, Feldman SR. Side effects of common acne treatments. Expert Opin Drug Saf. 2013;12:39-51. doi:10.1517/14740338. 2013.740456.

16. L.F. E, a.C. K, C.P, et al. Evidence-based recommendations for the diagnosis and treatment of pediatric acne. Pediatrics. 2013;131:S163-S186. doi:10.1542/ peds.2013-0490B.

17. Williams HC, Dellavalle RP, Garner S. Acne vulgaris. Lancet. 2012;379(9813):361-372. doi:10.1016/ S0140-6736(11)60321-8.

18. Nascimento GGF, Locatelli J, Freitas PC, Silva GL, Piracicaba UM De. Antibacterial Activity of Plant Extracts and Phytochemicals on Antibiotic-. Brazilian $J$ Microbiol. 2000;31:247-256. doi:10.1590/S151783822000000400003 .

19. Kurniawati PT, Soetjipto H, Limantara L. ANTIOXIDANT AND ANTIBACTERIAL ACTIVITIES OF BIXIN PIGMENT FROM ANNATTO (Bixa orellana L.) SEEDS. Indones $J$ Chem. 2010;7(1):88-92. http://pdmmipa.ugm.ac.id/ojs/index.php/ijc/ article/view/281.

20. Bhalodia NR, Nariya PB, Shukla VJ. Antibacterial and antifungal activity from flower extracts of Cassia fistula L.: An ethnomedicinal plant. Int $J$ PharmTech Res. 2011;3(1):160-168. doi:10.1016/j.jep.2007.04.008.

21. Mould FL, Kliem KE, Morgan R, Mauricio RM. In vitro microbial inoculum: A review of its function and properties. Anim Feed Sci Technol. 2005;123-124 Part 1:31-50. doi:10.1016/j.anifeedsci.2005.04.028. 